\title{
Building defects: survey and impact over sustainability
}

\author{
E. Costanzo \\ Laboratory for Construction and Conservation LCC1-EPFL, \\ Ecole Polytechnique Fédérale de Lausanne, Switzerland
}

\begin{abstract}
It is commonly assumed that existing building stock management has a great potential to achieve better sustainable development results.

Durability of existing building components determines the period of their performance decay and, therefore, maintenance and refurbishment cycles, which, owing to their recurrence, may have relevant effects on the environment and the economy.

Knowledge of building pathology phenomena and, therefore, defects prevision during building operation, can lead to less frequent and more appropriate maintenance and renovation, helping lengthen service life (and durability) of components, and so avoiding new production and construction impacts and reducing recurrent $C \& D$ waste due to frequent replacement.

This paper shows the advantages of an archive on building pathology, created from cases of expertises and consultancies, and a proposal of a protocol of survey, to collect in-field data and address the use of the archive towards operational and post operational building performance assessment and management.

Keywords: construction elements, failure, survey, post occupancy evaluation, durability, indoor health.
\end{abstract}

\section{Introduction}

The operational phase in building life is the moment where the occupant has to experience and to profit of the existing structure.

This phase lasts at least 50 years in average and is the very aim of construction, where the user's needs are compared with real building performances and their eventual decay due to aging: 
- $\quad$ health, safety and security,

- functionality and efficiency of technical and space elements

- $\quad$ psychological, social, cultural and aesthetic performances.

Moreover, - if we consider an existing building as an heritage all citizens has to profit of as enlarged users of the built environment - environmental and economic issues, such as impacts on natural material and energy resources consumption due to operation, land occupation, adaptation to present crucial uses and other externalities, are also to be taken into account.

Since the ' 1970 s Post Occupancy Evaluation (POE) models have been developed to estimate real occupancy performances of housing rapidly constructed after the Second World War, when premature damages and degradations began to be evident. The feedback evaluation of performances and failures has several advantages:

- socially, to demonstrate lacking of knowledge of needs, expectation, behaviour and lifestyle of present occupants at the age of construction;

- technically, to assemble useful information on design, construction and renovation "correctness", thus contributing to assess service life [1] and negative effects of building components and products.

The feedback data are precious to building industry, to maintenance and management planning, to the assessment of compliance to new standards that occurred after the construction. It is the case of energy saving directives but also of building products health and environmental standards, nowadays more and more imperative in Europe [2].

Information from inspection of buildings, - when the investigations are properly designed - gives direct correlation between the state of components, exposure environment and the building use [3].

The trend for systematisation of such information is alighted by recent international acts and procedures and by the spread of master study courses for surveyors: i.e. the UK 2004 "housing act" requiring re-launched training for building inspectors [4] and the on going "air quality campaign" in France [5].

Failures that occur in buildings are among the data that are necessary to gather in order to evaluate varied building performances from the design phase. The concern of measuring the relationship between occupants' satisfaction and building technical performance is expressed by recurring complaints on comfort deficit (acoustic and lightning levels, temperature and humidity, ventilation, indoor air quality) as consequences of components failures or inapt employ of materials and techniques. Quantitative and qualitative evaluations are necessary to attain the comparison between measured and perceived levels of performance.

Expertises supplied by EPFL for thirty years in French Switzerland, as a service to owners, architects, building estate managers, renters and lawyers constitute an archive basis on actual state of running modern buildings. The available database contains information on corrupted materials, components failures, performance decay, agents, anomalies localization, factors causing degradations, defects and responsibilities.

Most of pathologies have been found to be systemic, first of all the ones where components failures and low indoor comfort are strictly related [6]. 
Nevertheless our available information should be enriched by a more systematic approach in measuring micro-environmental loading, building components degradation and in investigating occupants' perception. The relationship between these three factors is still unexplored, as well as effects on human health due to indoor pollutants; yet some of them are generated by building products and by their degradation.

Therefore we consider it necessary to broaden the building pathology enquiry field, fostering the interdisciplinary approach of three combined issues: socioeconomic occupants' satisfaction, environmental and engineering studies of indoor environment, architectural topic of components' durability.

\section{In field data collection}

Survey is the first cognitive moment of the building, of its components features, of their aging and use conditions but also of performance level they actually supply. It can represent much more than a simple "visual appreciation" so leading to diagnosis, if the surveyor carries it on according to a procedure and by help of a basic equipment that allows him to gather numbers of targeted information.

Normally a first recognition visit is followed by a more detailed direct survey, where adopting further diagnosis-oriented investigations and non-destructive or little invasive tests and monitoring. The surveyor analyses:

$\begin{array}{ll}\text { - } & \text { Materials and their labour } \\ \text { - } & \text { Constructional techniques and historical stratification } \\ \text { - } & \text { Degradation phenomena and evolution } \\ \text { - } & \text { Hygienic-sanitary conditions, health and comfort (IAQ, IEQ) }\end{array}$

Moreover further instrumental testing, technically more complex and expensive, may claim particular skills and experience. Decision to deepen the diagnosis is established by the surveyor and can be rather subjective. An indiscriminate adoption of such methods might be a burden for a cost-effective diagnosis, and for repeatability of building performance evaluation methods.

It is necessary, in our opinion, a rule to scientifically define the relationship between the presence of particular building materials and products, their degradation, health concern and measurable in use performances.

In the last decade different campaigns in Switzerland dealt with building pathology diagnosis and indoor comfort, supplying separate tools of building performance evaluation [7] [8].

We are working at a tool, a protocol, to make the survey methods repeatable and to integrate available information in our building pathology database.

\subsection{Preliminary recognition visit}

During the first visit, following a quick documentary research and simple questions to owners, clients, occupants, the surveyor will gather general data and attain a rough estimation, by the aid of descriptive forms. 
Table 1: $\quad$ General data for report of preliminary recognition visit.

\begin{tabular}{|l|l|l|}
\hline Data to report: \\
\hline Conditions of engagement & Data on client & Client's mandate or complaint \\
\hline Geographical information & Building localization & Date of inspection and weather \\
\hline Functions of the building & Date of construction & Date of renovation - maintenance \\
\hline Activities per space/room of inspected units & Occupational density \\
\hline Demographic information of occupants (position, age, gender, education) \\
\hline $\begin{array}{l}\text { Presence, type, conditions of services (electrical, gas, cold water plumbing and sanitary fittings, } \\
\text { hot water, drainage) }\end{array}$ \\
\hline $\begin{array}{l}\text { Main technology (prefabricated, Hi-Tech mechanic assembly, main structural and envelop } \\
\text { materials) }\end{array}$ \\
$\begin{array}{l}\text { Rough evaluation of overall building components conditions } \\
\text { i.e., roofs, chimneys, flashings, parapets, gutters, main walls damp proof courses and } \\
\text { ventilation, joinery and woodworks, decorations and finishes, ceilings, walls and partitions, } \\
\text { floors, joinery and woodworks. }\end{array}$ \\
\hline Rough evaluation, rating of degradation percentage and level \\
\hline Pre-diagnosis
\end{tabular}

Eventual degradations will be rapidly appreciated according to four levels: light, average, heavy, irreparable and by rough estimation of percentage or number of components affected by degradation. A first pre-diagnosis will be hypothesised, also underlining opportunity of further survey.

\subsection{Building defects detailed survey: protocol of investigation}

The tools that compose the protocol in course of development are:

1. A check list for sensorial survey, mainly subjective visual, odour, tactile, noise assessment, to gather qualitative data on presence/lack of symptoms and anomalies (Figure 1), as well as on presence/lack of building products that can be sources of indoor pollution such as fibrous or foam insulations, textured paints and coatings, pressed wood products, wet or damp carpets, tissues, glues, some rocks, etc [9].

2. A questionnaire for occupants. (Table 2)

Aid tools for more detailed inspections are:

3. A list of reference to methods of direct survey. The surveyor uses common instruments such as insulated light and extension lead, binoculars, plumb line, hand mirror, camera, assorted screwdrivers, digital level meter for angles and gradients, laser measurer, capacitance moisture meter, endoscope, rubber tipped hammer, metal detector and stud sensor, concrete reinforcement corrosion detector, inflatable bags and smoke testing, coloured dyes for tracing drain runs, but also more specific equipment [10] for measuring materials strength or detect invisible condensation (dew point indicator). (Figure 2)

4. A list of reference to instrumental procedures of testing and monitoring to quantify IEQ effects due to building components pathology or inappropriate use of building materials, absorbing or emitting ozone, formaldehyde, fibres, asbestos, radon, bacteria and moulds, VOCs. 


\begin{tabular}{|c|c|c|}
\hline 8 & \multicolumn{2}{|c|}{$\begin{array}{l}\text { Sensorial Perception: } \\
\text { - Visual: Colour, surface texture, continuity, deformation } \\
\text { - Tactile sensation: Temperature, moisture content, } \\
\quad \text { consistence (tenacious, friable); hardness (tender, soft, } \\
\quad \text { hard) } \\
\text { - Sound: different sound levels at impact } \\
\text { - Taste: salted (efflorescences); sweet, bitter, none } \\
\text { - Odour: acre, sweet, }\end{array}$} \\
\hline & \multirow{6}{*}{$\begin{array}{l}\text { Surveyor perception } \\
\text { Visual sensation } \\
\text { Where water leaked? } \\
\text { Are there interior or exterior stains? } \\
\text { What is their chromatic attribute? What } \\
\text { the degrees of intensity? What the } \\
\text { degrees of brightness (clear, dark)? } \\
\text { Does it make patterns along fissures, } \\
\text { sills, roof drains? Are there } \\
\text { efflorescences (white stains)? } \\
\text { Is the surface flat, smooth, corrugated, } \\
\text { cracked? What are the materials at } \\
\text { perception? What materials-parts were } \\
\text { wetted? What are the materials affected } \\
\text { by anomalies? Are previous repair } \\
\text { present? Are there open or corrupted } \\
\text { joints? }\end{array}$} & \multirow{6}{*}{$\begin{array}{l}\begin{array}{l}\text { Questions to } \\
\text { occupants } \\
\text { Visual sensation: }\end{array} \\
\text { How long have } \\
\text { water leaked? } \\
\text { Since when in a } \\
\text { visible way? } \\
\text { What were the } \\
\text { water patterns in } \\
\text { the building } \\
\text { history? } \\
\text { Under what } \\
\text { meteorically } \\
\text { condition leak } \\
\text { occurs: after } \\
\text { abundant rain, } \\
\text { with what } \\
\text { combination } \\
\text { wind-waterfall? }\end{array}$} \\
\hline A) Ceiling Finishes. (code 45/1) & & \\
\hline Material: Plaster & & \\
\hline $\begin{array}{l}\text { Moisture stains and corrugation } \\
\text { of rendering }\end{array}$ & & \\
\hline & & \\
\hline $\begin{array}{l}\text { B) Suspended ceiling (code 45/3) } \\
\text { Material: gypsum-board }\end{array}$ & & \\
\hline
\end{tabular}

Figure 1: Example of checklist for sensorial survey in two cases of water leak trough flat roof.

Existing checklists, building codes, standards and past good practices form the references to outline questionnaires for owners, managers and occupants [11].

\section{Table 2: $\quad$ Abstract of the questionnaire for occupants.}

\begin{tabular}{|l|}
\hline Data and evaluations to be supplied by the occupants \\
\hline Comfort per type of space (rated from 1 to 4 , according to different spaces/rooms) \\
Scores for temperature, ventilation, humidity, air movement, air freshness, odour, noise distraction, \\
visual privacy, conversation privacy, natural and artificial lighting comfort, glare from light, \\
perceived quality of building materials \\
\hline Functionality of components: \\
Scores: easy (simple, intuitive) to use, equitable use (for different abilities), resistant, safe. \\
\hline Maintainability: easy to care, difficult to care, frequency of maintenance \\
\hline Ecology: energy saving (bill cost, Energy Index), kind of cleaning, frequency of cleaning \\
\hline Health problems: allergies, headaches, light disturbs (complaints, frequency of disturbs) \\
\hline
\end{tabular}

During the detailed inspections the pre-diagnosis is confirmed or rejected. This may require the use of instrumental testing that is to be indicated by the surveyor himself. He has to judge the opportunity and the kind of such check. Figure 2, case A, illustrates the characterisation of symptoms like stains, 
efflorescence, and moulds. One third to one half of buildings have damp conditions that may encourage development of such pollutants, often causing allergic reactions - including asthma - and spread of infectious diseases. Related symptoms described by occupants may be sneezing, watery eyes, coughing, shortness of breath, lethargy, fever and digestive problems.

Owing to the correlation of factors like temperature, relative humidity, thermal transmittance, condensation and probable presence of indoor air pollutants (VOCs, formaldehyde, moulds, odours) in this pathology case, the surveyor might go through the indicated instrumental monitoring.

More generally, building products can actively and indirectly contribute to pollution not only as a source of indoor pollution but also by absorbing or reacting to $\mathrm{NOx}, \mathrm{SOx}, \mathrm{CO} 2$.

\section{Impacts on sustainability}

Life cycle thinking is peculiar in sustainability evaluation. Within this approach building pathology distresses:

- Mentioned health and satisfaction of occupants during operation

- Functionality of components

- Service life of the original and repaired components, hence waste avoidance

Degree of repair intervention and through time easiness to care. end of life treatment (discharge, incineration, special processing, etc.)

Choice of materials and of their quantities, also due to repair frequencies, determines associated environmental impacts. That's why service life, is mentioned as a parameter to be taken into calculation of resources consumption and emission flows [12].

Knowledge of negative cases and codification of failure modes, contributing to service life prevision, effects on micro-environmental and occupants' comfort, can improve sustainability performances.

\section{Results}

The ongoing work, as illustrated, will converge to a method of data collection to integrate components pathology analysis with occupational and indoor environment information, within a holistic approach to building performance evaluation.

\section{Conclusions}

Data gathering during expertises on building pathology is to standardize, in order to have replicable results and contribute to post occupancy evaluation. 


\begin{tabular}{|c|c|c|}
\hline Path & irect survey & Instrumental te \\
\hline $\begin{array}{l}\text { Case A: } \\
\text { Detachment of the paper, stains, } \\
\text { moulds, fungal growth, Odour } \\
\text { Pre- diagnosis: } \\
\text { - Insufficient thermal } \\
\text { insulation of the wall (U value) } \\
\text { Excessive air-tightness of } \\
\text { the windows } \\
\text { - Excessive air moisture content } \\
\text { in the room (insufficient } \\
\text { ventilation) }\end{array}$ & 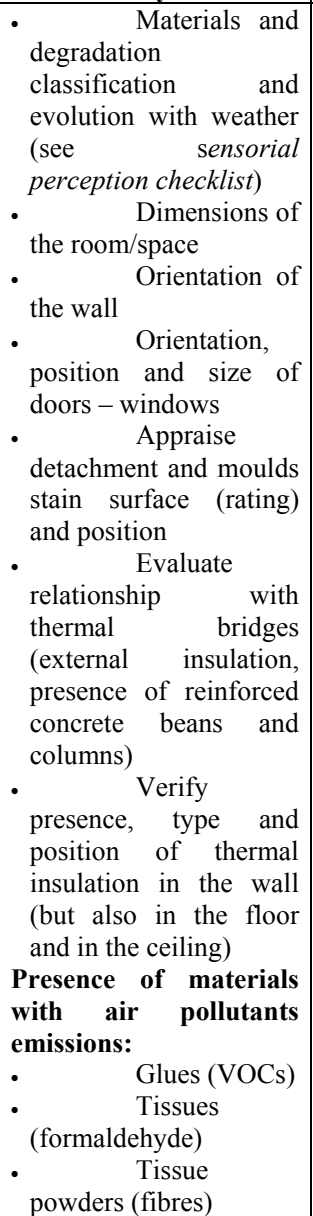 & 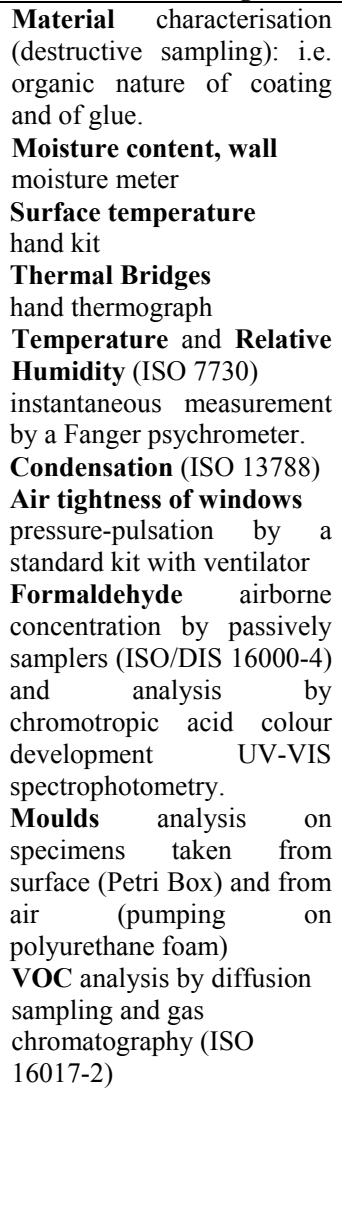 \\
\hline $\begin{array}{l}\text { Case B: } \\
\text { Displacement a } \\
\text { the indoor gypsu } \\
\text { Pre- diagnosis: } \\
\text { Shifts of the loa }\end{array}$ & $\begin{array}{l}\text { - Check activity } \\
\text { and evolution of } \\
\text { fissures at visual and } \\
\text { probe (indoor-outdoor) } \\
\text { Presence of materials } \\
\text { with possible dangerous } \\
\text { emissions: } \\
\text { Isolating mats } \\
\text { behind the gypsum } \\
\text { boards (fibres) }\end{array}$ & 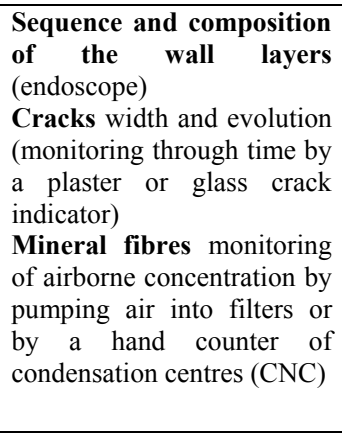 \\
\hline
\end{tabular}

Figure 2: Examples of detailed inspection checklist. 
A more rigorous approach in surveying can be put to point by putting into practice a campaign of oriented expertises. These ones should simultaneously take advantage of empirical and scientific methods, both direct sensorial ones, which are peculiar of current building pathologies inspections - and instrumental monitoring, typical of IEQ building physics and chemical investigations. Furthermore, a sustainable approach cannot neglect interviews to occupants and their appreciation. In some standard cases, as the presence of moulds and water leak, such approach could allow fixing:

Reliability of pre-diagnosis survey visit

Proper testing and a standardised series of empirical detection procedures

Relationship between qualitative pre-diagnosis direct survey results and quantitative measurement.

\section{References}

[1] International Organization for standardization, series ISO 15686: Buildings and constructed assets - Service life planning. ISO 156861:2000 General principles; ISO 15686-3:2002 Performance audits and reviews; ISO 15686-6:2004 Procedures for considering environmental impacts.

[2] European Commission Construction Unit, http:/europa.eu.int/comm/ enterprise/construction/mission en.htm.

[3] P. Jernberg, C. Sjöström, et al., Service Life and Durability Research, Proceedings of Joint CIB W080/RILEM TC 140 -Prediction of Service Life of Building Materials and Components - Guide and Bibliography to Service Life and Durability Research for Buildings and Components, Part I, CIB report 295, 2004.

[4] BRE, British Research Establishment, http://www.bre.co.uk/.

[5] Observatoire de la qualité de l'air, http://www.air-interieur.org/.

[6] F. Iselin, Plaidoyer pour des rénovations durables - Leçons de mille et une expertises. C\&R 5, pp. 52-56, May 2005.

[7] Publications of Programme PI-BAT, Entretien et rénovation des constructions, Office Fédérale des Questions Conjoncturelles, Berne 1990-95.

[8] Office Fédéral de la Santé Publique, Liste de contrôle pour la première évaluation de la charge polluante à l'intérieur des bâtiments existants, Berne, Suisse, 2000.

[9] Ibid., Fiches d'évaluation : fiches thématiques et de matériau (20 sheets)

[10] P. Glover, Building Surveys, Elsevier: Oxford, pp. 4-6, 2003.

[11] W. F.E. Preiser, J. Vischer, Measuring instrument for Building Performance Evaluation (Appendix), Assessing Building Performance, Elsevier, pp. 209-237, 2005.

[12] AFNOR, NF P01-10:2004, Environmental Quality of construction products - Environmental and Health Declaration of Construction Products (Within the ISO/TC59 for ISO/TS 21931). 